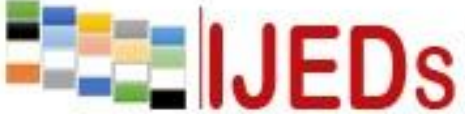

http://ijeds.ppj.unp.ac.id/index.php/IJEDS

\title{
ANALYSIS OF PRODUCTIVE TEACHERS COMPETENCE DRAWING WITH SOFTWARE IN VOCATIONAL SCHOOL
}

\author{
*Yocky Syaida Adha Putra ${ }^{1}$, Jalius Jama ${ }^{2}$ and Azwar Inra ${ }^{3}$ \\ ${ }^{1}$ Graduate Program of Vocation Technology Education Faculty of Engineering, \\ Universitas Negeri Padang, Indonesia. \\ ${ }^{2}$ Lecturer Faculty of Engineering, Universitas Negeri Padang, Indonesia \\ ${ }^{3}$ Lecturer Faculty of Engineering, Universitas Negeri Padang, Indonesia \\ Email: yocky.syaidaa@gmail.com
}

*Corresponding Author, Received: November 12, 2019, Revised: December 10, 2019, Accepted: December 21, 2019

\begin{abstract}
The research objective is to determine the competencies needed by productive teachers to draw with software so that graduates have the competencies desired by the business world and the industrial world. Descriptive qualitative research methods. The data in this research are descriptive narrative. Data sources from interviews, observations and documentation. The resource persons consisted of planning and supervision consulting firms, lecturers majoring in building engineering education at Padang State University and teachers teaching drawing with software at SMK N1 Padang and at SMK N1 SUMBAR. Data collection techniques with interactive and non-interactive. Data analysis techniques using qualitative techniques. Data validity is done by Source Triangulation. The results of the analysis: The teacher must master the science of drawing, cost estimation, time, quality and $\mathrm{K} 3$. The teacher must motivate and explain to graduates drawing with software how the work environment work environment. The teacher must teach good communication ethics and soft skills. The teacher must follow the development of software and also master its use. Teachers must be able to use IT to add references and self-development.
\end{abstract}

Keywords : Competencies Analysis of Productive Teachers, Drawing with Software, 21st Century Teacher Competence

\section{INTRODUCTION}

Vocational school is a secondary education that prepares graduates to enter the workforce. One of the majors in SMK is the Building Drawing Technique which studies the planning, calculation and repair of buildings. According to data from the Central Statistics Agency in 2017 SMK is the largest contribution to unemployment which is $11.41 \%$ of the total education of all levels of education in Indonesia. This is certainly inversely proportional between the objectives of SMK as educational institutions that 


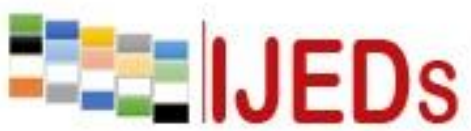

http://ijeds.ppj.unp.ac.id/index.php/IJEDS
International Journal of Educational Dynamics

Vol. 2 No. 1 (pp. 151-159) Desember 2019

p_ISSN 2655-4852

e_ISSN 2655-5093

prepare graduates ready for work. Secretary of the Directorate General of Training and Productivity Development (Binalattas) Ministry of Manpower (Kemenaker) (2017) "assesses the large number of unemployment rates in vocational high school (SMK) graduates is caused more by the inequality between vocational education curriculum and industry needs".

Ministry of Education and Culture Hamid Muhammad (2018) revealed that one of the causes of unemployment is the quality of graduates who do not meet the standards expected by the industry. The solution, according to Hamid, is stated in Presidential Instruction (Inpres) No. 9 of 2016 concerning SMK Revitalization. These include "adjusting the curriculum to industry needs, increasing the number and competence of teachers, revitalizing facilities and practical tools. Also increased competency testing, certification and accreditation, as well as increasing vocational cooperation with industry ". From interviews conducted by researchers at a planning and supervision consulting firm in Padang in October 2018, they got an answer why they did not employ vocational alumni as photographers: The company did not have time to train workers because the work was so piled up. The company only wants workers who truly understand what to do.

Teacher competence is very influential on the success of the teaching and learning process, and motivation. This was revealed by Diasty, et al (2017) who stated that teacher competence had a positive effect on student achievement later Puri (2012) stated that there was a positive relationship between teacher competency and motivation and student learning achievement simultaneously. The description above can be found that teacher competence is very influential on learning outcomes and student motivation. The above research is some research that states the importance of teacher competence on student success. The purpose of this study is to find out what competencies teachers must have productive drawing with software, in order to produce graduates who are needed by the business world and the 21 st Century industrial world. 


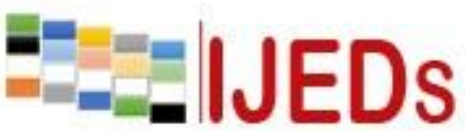

http://ijeds.ppj.unp.ac.id/index.php/IJEDS
International Journal of Educational Dynamics

Vol. 2 No. 1 (pp. 151-159) Desember 2019

p_ISSN 2655-4852

e_ISSN 2655-5093

\section{METHOD}

This type of research uses a qualitative descriptive approach. Resource persons consisted of FT-UNP Lecturers, Productive Drawing Teachers with Padang N1 Vocational High School and West Sumatra N1 Vocational School, Planning and Supervision Consultant Company under the auspices of the Padang City INKINDO DPP. In this study, the data collected included in-depth interview data but referred to existing general competencies, observations, and documentation. In selecting company researchers used a purposive sample technique. In addition, researchers also use snowball sampling techniques to saturate the results of interviews obtained so that interactive models can be done. Snowball sampling technique is a method for identifying, selecting and taking samples in a network or continuous chain of relationships.

In data analysis, researchers use an interactive model, whose elements include: Data Reduction, Data Presentation / Display, Data Verification (Conclusions drow-ing / verifiying). So that the data in this study can be justified as scientific research, it is necessary to test the validity of the data. The data validity test can be carried out. Credibility, Transferbility, Dependenbility and Confirmability.

\section{RESULTS AND DISCUSSION}

The study was conducted from December 2018 to February 2019 in the Department of Building Engineering Education, State University of Padang, State Vocational School 1 West Sumatra, State Vocational School 1 Padang and Planning and Supervision Consultants under the auspices of the selected INKINDO - Padang DPP. The following description of research data: Interview Data, Interview data is the result of interviews conducted at the Department of Building Engineering Education, State University of Padang, State Vocational School 1 West Sumatra, State Vocational School 1 Padang and Planning and Supervision Consultants under the auspices of DPP INKINDO - Padang who have been selected. Interviews conducted are in-depth interviews based on general competencies that exist at this time. Documentation Data, Documentation data consists of photographs, permission to conduct research issued by Padang State University and a statement that the researcher has conducted research issued by each agency where the researcher conducts research. 


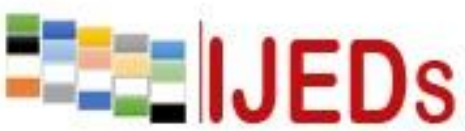

http://ijeds.ppj.unp.ac.id/index.php/IJEDS
International Journal of Educational Dynamics

Vol. 2 No. 1 (pp. 151-159) Desember 2019

p_ISSN 2655-4852

e_ISSN 2655-5093

The data analyzed is the data obtained from the results of interviews, interviews conducted recording and then made the script of the results of the interview can be seen in the appendix. The data that has been obtained is then performed Data Reduction (Data Reduction), Data Presentation (Display), and Data Verification (Conclusions drawing / Verifying).

Data verification is a form of verification that the results of the interviews conducted. In this study the author verifies the data in the form of a permit to conduct research issued by Padang State University and a statement that the researcher has conducted research issued by each agency where the researcher conducts research on complete data can be seen in the appendix.

In testing the credibility of the data, researchers used source triangulation in which the researcher checked the answers obtained from the Lecturer drawing with the software Department of Civil Engineering FT-UNP, the Teacher drew with the software of West Sumatra N1 Vocational School and Vocational High School N1 Pa-dang, and Planning and Supervision Consultant Company which has been selected by DPP INKINDO Kota Padang, along with a source triangulation chart.

Interviews for each resource person were analyzed and the results of the interview interviews were obtained. After the answers to the agencies are obtained, an analysis of the answers to the interviews of the three institutions is carried out and interviews are obtained in this study.

In Indonesia, teacher competency is regulated by Government Regulation number 19 of 2005 concerning national education standards, article 28 paragraph 3 of teacher competence includes "pedagogical competence, personal competence, social competence, and professional competence obtained through professional education". In achieving the teacher's competence, there is a close relationship between the competencies that must be possessed or that will be achieved by the graduates taught by the teacher. Then the analysis of the competence of teacher drawing with 21 st century software in this study is based on the competence of graduates drawing with 21 st century software that has been conducted interviews with informants. The following analysis of 21 st century teacher competencies: 
- The teacher must understand the characteristics of students, and the teacher must also understand in terms of student confidence and how to interpret the forms of gratitude for the technological gift.

- The teacher also understands from the physical, moral, spiritual, social, cultural, emotional, and intellectual aspects of the students being taught.

- Teachers can motivate students to always update their knowledge through various sources such as the internet and library.

- The teacher must teach and give examples of good and correct verbal and non-verbal communication methods both within the school environment and outside the school environment.

- The teacher is able to explain and teach karma or manners as well as courtesy in accordance with religious norms and customs to students.

- The teacher must model and teach students how to use appropriate and interesting language.

- The teacher teaches how students value and accept the opinions of others.

- Teachers must have a sense of responsibility and not do plagiarism, to achieve this competency the teacher must teach and apply a sense of responsibility to students, as well as provide an understanding of what plagiarism is and what plagiarism risks are.

- Teachers must be able to find references from various sources, especially the use of the internet as a reference source. Thus the teacher can motivate and direct students to update their knowledge with technological developments.

- The teacher must be able to state the logical reasons for each topic taught, so that students can come up with logical reasons in giving an opinion on what they are doing.

- The teacher must make it a habit to give targets to assignments made by students and apply the standard of each lesson.

- The teacher must provide and describe what the standard rules of reference in drawing to students so that students understand the standard of reference that they will use when entering the workforce.

- The teacher must build and guide so that the formation of imagination, improvisation, insight and logic in building construction in students and will 
facilitate students in drawing with software when doing assignments while in the world of work.

- Teachers must instill an attitude of courtesy, friendliness and responsibility since the school bench to students.

- The teacher must teach and apply entrepreneurship, independence and a sense of responsibility to students in drawing with software.

- The teacher must familiarize students to work together in the form of group assignments and also individually, so students are accustomed to working in teams or individually in the world of work.

- Teachers must teach discipline in work and in attitude, accuracy in work and honesty at work.

- The teacher must teach to share in scientific matters to students such as applying peer tutors, so that students easily share knowledge with others.

- The teacher illustrates and illustrates in the form of motivation how pressures in the world of work, what will be done, the atmosphere of the world of work, the discipline of the world of work that students will face after entering the workforce and also accompanied by fieldwork practices and various comparative studies to companies- companies that the students will enter.

- Teachers must teach and guide so students are able to get closer to new people and interact with new people.

- The teacher teaches good and right questions and motivates students to develop curiosity about drawing with software.

- The teacher also teaches and applies so that students are able to learn independently (self-taught) in increasing student knowledge of drawing with software.

- The teacher must also teach students how to maintain and install applications drawing with software.

- The teacher teaches students how to modify images effectively, quickly and correctly.

- The teacher explains the $\mathrm{K} 3$ standard on building construction drawings (buildings, irrigation and transportation) that have been made to students. 


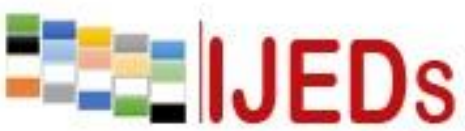

http://ijeds.ppj.unp.ac.id/index.php/IJEDS
International Journal of Educational Dynamics

Vol. 2 No. 1 (pp. 151-159) Desember 2019

p_ISSN 2655-4852

e_ISSN 2655-5093

From the analysis, the following conclusions are obtained: 1) The teacher must be able to explain and understand the science of drawing, cost estimation, time, quality and $\mathrm{K} 3$ on building construction, irrigation and transportation. Because so far students are only taught in building construction so companies that have sub-fields of irrigation and transportation cannot accommodate graduates drawing with software to work on them. 2) Teachers must motivate and explain to graduates drawing with software how the work environment, the pressures that will be faced in the world of work and what they will do in the world of work. 2) The teacher must teach good and correct communication ethics and soft skills and the teacher while maintaining the authority as a teacher. 3) Teachers must follow the development of software that is always up to date from time to time and also mastered the software. 4) Teachers must be able to use IT development to add references and self-development. For educational institutions as a reference or picture in developing productive teacher competencies drawing with software. For educators and prospective educators can understand what is wanted by the business world and the industrial world today.

\section{CONCLUSION}

From the analysis, the following conclusions are obtained: 1) The teacher must be able to explain and understand the science of drawing, cost estimation, time, quality and $\mathrm{K} 3$ on building construction, irrigation and transportation. Because so far students are only taught in building construction so companies that have sub-fields of irrigation and transportation cannot accommodate graduates drawing with software to work on them. 2) Teachers must motivate and explain to graduates drawing with software how the work environment, the pressures that will be faced in the world of work and what they will do in the world of work. 2) The teacher must teach good and correct communication ethics and soft skills and the teacher while maintaining the authority as a teacher. 3) Teachers must follow the development of software that is always up to date from time to time and also mastered the software. 4) Teachers must be able to use IT development to add references and self-development. For educational institutions as a reference or picture in developing productive teacher competencies drawing with software. For educators and prospective educators can understand what is wanted by the business world and the industrial world today. 


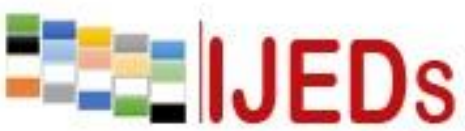

http://ijeds.ppj.unp.ac.id/index.php/IJEDS
International Journal of Educational Dynamics

Vol. 2 No. 1 (pp. 151-159) Desember 2019

p_ISSN 2655-4852

e_ISSN 2655-5093

\section{REFERENCES}

Al-Bahra B. Ladjamudin. (2006). Rekayasa Perangkat Lunak: Edisi Pertama. Yogyakarta: Graha Ilmu.

Bachtiar S. Bachri. (2010). Meyakinkan Validitas Data Melalui Triangulasi Pada Penelitian Kualitatif. Surabaya: Universitas Surabaya.

Budi Warman. (2015). Pengaruh Kompetensi Profesional Guru dan Motivasi Belajar Terhadap Hasil Belajar Siswa Jurusan Akuntansi Di Sekolah Menengah Kejuruan Negeri 1 Kota Jambi. Jakarta: Universitas Terbuka.

Dedi Supriadi. (1994). Kreativitas, Kebudayaan dan Perkembangan IPTEK. Bandung: Alfabeta.

Depdiknas, (2005). Bab IV Rencana Pembangunan Pendidikan Nasional jangka panjang 2005-2025 dalam Rencana Strategis Departemen Pendidikan Nasional tahun 2005-2009.

Dewi Hernia Nengsih, (2017). Analisis Kompetensi Pedagogik Guru Dalam Pengelolaan Proses di SD Negeri 10 Mandonga. Wakapendik Vol. 2 No.7 2017.

Diasty Widar Hapsari, dkk, (2017). Pengaruh Kompetensi Guru Terhadap Prestasi Belajar Siswa SMK Negeri 2 Bawang. e-Proceding of Management, Vol.4, No.1 April 2017.

Edi Iswanto Sustrisno.(2009).Manajemen Sumber Daya Manusia. Jakarta: Kencana

Farida Retno Wardhani, (2017). Analisis Kompetensi Guru Berbasis Uji Kompetensi Guru Bidang Keahlian Administrasi Perkantoran Di Surakarta Tahun Ajaran 2015/2016. Surakarta: Universitas Sebelas Maret.

Hamka Lodang, dkk, (2013). Analisis Kompetensi Profesional Guru Biologi Sekolah Menengah Atas Negeri di Kota Makassar. Jurnal Bionature, Vol.14 No.1 April 2013.

Humaeroh, (2010). Hubungan Antara Kompetensi Profesional Guru Dengan Prestasi Belajar Siswa. Jakarta: Universitas Islam Negeri Syarif Hidayatullah.

Intan Rachma Dianti. (2017). Pengaruh Soft Skill dan Prestasi Belajar Terhadap Kesiapan Memasuki Dunia Kerja Pada Siswa Teknik Gambar dan Bangunan Kelas XI SMK Negeri 2 Bandar Lampung Tahun Pelajar 2016/2017. Lampung: Universitas Lampung.

Irma Ariyanti A, (2013). Analisis Kompetensi Guru Di SMK Negeri 1 Watapone, Kabupaten Bone. Makasar: Universitas Hasanudin.

Irwan Dwis Hasta Setiyawan. (2013). Pengaruh Prestasi Belajar Kejuruan dan Praktik Kerja Industri Terhadap Kesiapan Kerja Siswa Jurusan Teknik Pemesinan SMKN 3 Yogyakarta. Yogyakarta: Universitas Negeri Yogyakarta.

Jimmy Phaat, (2018). Rendahnya Kompetensi Guru Kejuruan. Padang: Harian Singgalang 10 Februari 2018.

Lexy J. Moleong, (2007). Metodologi Penelitian Kualitatif. Bandung: Remaja Rosdakarya.

Lutfi Didik Pratama. (2013). Pengaruh Kompetensi Guru Dalam Mengajar dan Motivasi Belajar Siswa Terhadap Prestasi Belajar Siswa Kompetensi Dasar Melakukan Prosedur Pengadaan Peralatan Kantor Kelas X SMK Negeri 1 Purwodadi Tahun 2011/2012. Semarang: Universitas Negeri Semarang.

Mulyasa, E, (2004). Menjadi Guru Profesional. Bandung: Remaja Rosdakarya. 
Mulyasa, E, (2006). Kurikulum Yang Disempurnakan. Bandung: Remaja Rosdakarya.

Mustari, (2015). Analisis Kompetensi Pedagogik Guru Produktif di SMK Negeri 1 Tarakan. Tarakan: Jurnal Kebijakan dan Pengembangan Pendidikan.

Parulian Hutapea dan Nurianna Thoha, (2008). Kompetensi Plus : Teori, Desain, Kasus dan Penerapan untuk HR dan Organisasi yang Dinamis. Jakarta: Gramedia Pustaka Utama

Peraturan Pemerintah Nomor 19 Tahun 2005: Tentang Standart Nasional Pendidikan.

Puri Utomo, (2012). Hubungan Antara Kompetensi Guru dan Motivasi Belajar Siswa Dengan Prestasi Belajar Siswa Kelas XI PGRI 1 Surakarta Tahun Ajaran 2011/2012. Surakarta: FKIP UNS.

Rista Sumaryaning Dewi, (2016). Analisis Kompetensi Pedagogik Guru Dalam Pelaksanaan Kurikulum 2013 Pada Pembelajaran Tematik Tema Sehat itu Penting Kelas V di SD Hj. Isriati Baiturrahman 1 Semarang Tahun Ajaran 2015/2016. Semarang: Universitas Islam Negeri Walisongo.

Sri Zakiyati, (2009). Pengaruuh Kompetensi Profesional dan Kompetensi Pedagogik Guru Ekonomi Akuntansi Terhadap Prestasi Belajar Siswa di SMK Kabupaten Magelang. Semarang: Universitas Negeri Semarang.

Sugiyono, (2006). Metode Penelitian Kuantitatif, Kualitatif dan R\&D. Bandung: Alfabeta.

Suharsimi Arikunto, (2016). Prosedur Penelitian Suatu Pendekatan Praktik. Jakarta: Rineka Cipta.

Sunaryo (2011), tentang Analisis Kompetensi Guru Fisika Dalam Mengimplementasikan Ktsp Di Smkn Di Provinsi Lampung. Lampung: UNILA.

Sunaryo, et al, (2002). Sejarah Pendidikan Teknik dan Kejuruan di Indonesia. Jakarta: Direktorat Pendidikan Menengah Kejuruan.

Surya Dharma, dkk, (2013). Tantangan Guru SMK Abad 21. Jakarta: Kemendikbud.

Sutopo, (2006). Metodologi Penelitian Kualitatif. Surakarta: UNS

Suyanto, (2007). Tantangan profesional guru di era global. Pidato Dies Natalis ke 43, UNY.

Syaodih Sukmadinata N. (2009). Metode penelitian Pendidikan. Bandung: Remaja Rosdakarya

Undang-undang nomor 20 Tahun 2005: Tentang Guru dan Dosen. 